\title{
VARYING APPLICATION OF MOST-FAVOURED-NATION PRINCIPLE IN INTERNATIONAL INVESTMENT TREATY
}

\author{
Robertus Bima Wahyu Mahardika ${ }^{1}$; Emmy Latifah $^{2}$ \\ ${ }^{1}$ The Assistant of The Public Notary of Ismiyati \\ ${ }^{2}$ Faculty of Law, Universitas Sebelas Maret \\ E-mail: robertusmahardika@gmail.com
}

\begin{abstract}
The aim of this study is to provide an academic framing of the philosophical foundation of the Most-favored-nation principle (MFN) in international investment law. The MFN principle is one of the most important principles in international law. In international investment law, MFN principle serves as a mechanism to create conditions in which foreign investors from many countries have equal opportunities to compete fairly in host country.
\end{abstract}

Keywords: most-favoured-nation principle; international investment law, philosophical foundation.

\section{A. INTRODUCTION}

Most-favoured-nation principle (here in after refers to as "MFN") became the pillar of the multilateral trading system (WTO system) in order to ensure that member states would not discriminate between their trading partner. MFN principle has been defined as a "cornerstone" of the World Trade Organization (WTO) and the "defining principle" of the General Agreement on Tariffs and Trade (GATT). Furthermore, MFN is one component of the principle of non-discrimination under international law. Indeed, non-discrimination can be appreciated in its internal aspect through the treatment accorded to nationals compared with that accorded to foreigners in national territory (national treatment). It can also be appreciated in its external aspect through the treatment accorded by the host state to foreigners of other nationalities (MFN treatment).

MFN clause in an investment treaty is fundamentally a promise between the two states party to the treaty that neither state will give to investors from any third state more favorable treatment than that given to investors from the other state party to the treaty (Stephen Fietta, 2005: 31). If more favorable treatment is provided to investors from a third state, an obligation arises to provide equivalent treatment to those investors benefiting from 
the MFN clauses (Stephan W. Schill, 2009: 502). While MFN clauses in investment treaties do not directly limit the fragmentation of international investment law, they can serve to harmonize the law under which foreign investors from different states operate (Bryan Coutain, 2009: 146). Absent MFN clauses, states will compete with one another to ensure that their investors receive the most favorable treatment given by a particular state, thereby generating a diversity of legal regimes. MFN clauses, by contrast, ensure that whenever benefits are given to investors from one state, they must also be provided to investors from any other state with an applicable MFN clause, thereby ensuring equality of treatment (Marie-France Houde, 2005: 129).

Considering the urgency of MFN in international investment treaty, it could be important to examine the philosophical foundation of MFN.

\section{B. PROBLEM STATEMENT}

Based on the problem the writer has elaborated above, the problems studied in the article is how to framing the philosophical foundation of the Most-favored-nation principle (MFN) in international investment law .

\section{RESEARCH METHODS}

This research was done by normative on the basis of secondary data, namely: primary legal materials, secondary, and tertiary related to philosophical foundation of the Most-favored-nation principle (MFN) in international investment law . The data obtained from the research literature and field research by qualitative analysis. The results of analysis were presented descriptively.

\section{DISCUSSION AND RESEARCH RESULT}

\section{The Concept of Most-Favoured-Nation (MFN) Principle and Its Developments}

The most-favoured-nation principle (hereinafter referred to as MFN) can be traced back to as early as 1226, when Emperor Frederick II of the Holy Roman Empire signed a treaty granting concessions to the citizens of Marseille that had previously only been available to citizens of Pisa and Genoa (Stanley K. Hornbeck, 1909: 395). In the beginning of development, during the eighteenth and nineteenth centuries, MFN principle commonly 
applied in the field of commerce, friendship, and navigation treaties (Endre Ustor, 1969: 157). It was quite broad, applying to the various range of issues such as rights, privileges, immunities, and exceptions with respect to trade, commerce, and navigation, or to duties and prohibition with respect to vessels, importation or exportation of goods (Endre Ustor, 1969: 157). The Treaty of Amity and Commerce between the United States and France of 1778 as well the Amity, Navigation and Commerce Treaty between the United State and Great Britain 1979 (it called "the Jay's Treaty) are some of prominent examples describe that the MNF Principle has been applied implicitly during that period.

Still at the early evolution, MNF principle was interpreted as a principle having conditional character (Yong Shik Lee, 2016: 36). It means that the benefits granted by a state were depending on the granting of the same value of concessions and commitments by the beneficiary State (Warren F. Schwartz \& Alan O. Sykes, 1997: 59-61). The rationale for conditional character was that it would not be fair for a state which did not reciprocate to receive the treatment for which it did not negotiate (Yong Shik Lee, 2016: 36). Furthermore, the emerging of unconditional approach begun at second half of the eighteenth century and the most notable example has been existing in the Chevalier-Cobden Treaty of 1869 between Great Britain and France (David Lazer, 1999: 9-10; Trebilcock et al, 2013: 55). Unlike conditional character of MFN, unconditional one did not required the beneficiary state to make the same concessions vis-à-vis the granting state as the MFN. The unconditional MFN of the Cobden Treaty became a standard practice in the numerous subsequent trade and commerce treaties throughout the world until the First World War (Richard Carlton Snyder, 1948: 239) and developed into the corner stone of an international commercial relations (Stanley Hornbeck, 1909: 395).

In the 1970s, the international community, represented by the International Law Commission (ILC), began to recognize the importance of MFN principles in international law. In 1978, the ILC began preparing "the Draft Article on the MFN" (hereinafter referred to as "ILC Draft") containing attempts to codify and develop the application of the MFN principle in treaties between states (Stephan W. Schill, 2009: 514). This document specifically defines the definition, scope, and impact of both conditional as well as unconditional characters of the MFN principle, the source of treatment, and the termination 
or suspension of the principle. Furthermore, ILC recommended to the General Assembly of the United Nations to establish a multilateral treaty relating to MFN as a binding legal instrument. Unfortunately, it was never happened (United Nations, 1979: 7-72). However, up to now, this draft has been considered to constitute a guideline for interpretation the MFN principle (Stephan W. Schill, 2009: 517).

ILC Draft distinguishes MFN principle into two: "MFN clause" and "MFN treatment”. Article 4 ILC Draft states:

"A most-favoured-nation clause is a treaty provision whereby a state undertakes an obligation towards another state to accord Most-favoured-nation treatment in an agreed sphere of relations."

Article 4 conveys the notion that MFN pledge is an international, i.e., inter-state undertaking. As such, the beneficiary of this undertaking is the beneficiary state and only through the latter state do the persons in a particular relationship with that state, usually its nationals, or the things in a similar relationship with it, enjoy the treatment stipulated by granting state (Sir Arthur Watts, 1999: 1803). It follows from the idea of the MFN clause, as described in Article 4 that the constitutive element of the MFN clause. Consequently, clauses that do not contain this element will fall outside the scope of the present articles even if they aim at effects similar to that of MFN clause. A case in point is Article XVII, paragraph 2 of the General Agreement on Tariffs and Trade (GATT), where "fair and equitable treatment" is demanded from the contracting parties with respect to import of products for immediate or ultimate consumption in governmental use (United Nations, 1970: 60). Other example is Article XIII, paragraph 1 of the GATT, which requires that the administration of quantitative restrictions shall be "non-discriminatory". While the MFN clause insures the beneficiary against discrimination, a clause promising non-discrimination will not necessarily yield the same advantages as a MFN clause (Sir Arthur Watts, 1999: 1806).

Article 4 of ILC Draft also stated that the grant of MFN treatment to another state by a MFN clause should be "an agreed sphere of relations". MFN clauses have been customarily categorized as "general" or "special" clauses. A "general" clause means a 
clause which promises MFN treatment in all relations between the parties concerned, whereas a "special" one refers to relations in certain limited areas (Sir Arthur Watts, 1999: 1807). Although states are free to agree to grant to each other MFN treatment in all field which are susceptible to such agreement, this is rather an exception today. The usual type of a "general clause", however, does not embrace all relations between the respective countries. It refers to all relations in certain areas; thus, for example, "in all matters relating to trade, navigation, and all other economic relation (Sir Arthur Watts, 1999: 1807). MFN clause may be less broad but still general, the "general clause" of Article I, paragraph 1 of the GATT being well-known example.

The areas in which MFN clauses are used are extremely varied. A tentative classification of the areas in question, which does not claim to be exhaustive, may be given as follows (Sir Arthur Watts, 1999: 1808):

(a) International regulation of trade and payments (exports, imports, and customs tariffs).

(b) Transport in general and treatment of foreign means of transport (in particular ships, airplanes, trains, motor vehicles, etc.).

(c) Establishment of foreign physical and juridical persons, their personal rights and obligations.

(d) Establishment of diplomatic, consular, and other missions, their privileges and immunities and treatment in general.

(e) Intellectual property (rights in industrial property, literary, and artistic rights).

(f) Administration of justice, access to court and to administrative tribunals in all degrees of jurisdiction, recognition, and execution of foreign judgments, security for cost, etc.

Meanwhile, Article 5 Draft Article on MFN ascertain:

"Most-favoured-nation treatment is treatment accorded by the granting state to the beneficiary state, or to persons or things in determined relationship with that State, not less favourable than treatment extended by the Granting State to a third State or to persons or things in the same relationship with that third State."

Article 5 establishes the juridical meaning of the MFN treatment. In some languages, MFN treatment is expressed as most favourable treatment. While the obligation to accord 


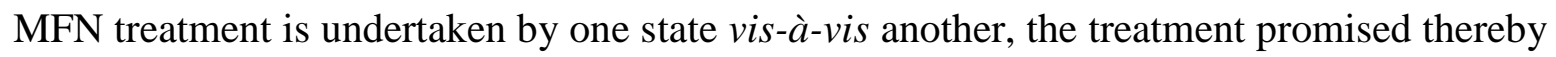
is one actually given in most cases to persons or things, and only in some cases to states themselves (e.g. in cases promising MFN treatment to embassies or consulates) (United Nations, 1979: 21). By what methods and under what circumstances the persons or things concerned will come to enjoy the treatment depend on the intention of the parties to the treaty in question and on the internal law of the granting State (United Nations, 1979: 21).

The words "persons or things" includes any persons or things that can constitute the object of treatment. The expression "persons or things" must be understood as covering persons and things in the natural and juridical meaning attributed to those words in the different languages and legal system of the world. In particular, the world "things" embraces not only corporeal and incorporeal things but inter alia activities and services. Indeed, activities such as the exercise of certain trades and professions, entry into port of ships, etc. can also be the objects of MFN treatment (United Nations, 1979: 21).

Moreover, the persons or things whose treatment is in question have to be in a "determined relationship" with the beneficiary state and that their treatment is contingent upon the treatment extended by the granting state to persons or things which are in the "same relationship" with the third state. A "determined relationship" in this context means that the relationship between the state concerned and the persons or things to whom and to which the MFN treatment is applicable and this determination has to includes, obviously, the link between the beneficiary state and the persons or things concerned. Such relationships are nationality or citizenship of persons, place of registry of vessels, state of origin or products, etc. Under Article 5, the beneficiary state can claim MFN treatment in respect of its nationals, ships, products, etc. only to the extent that the granting state confers the same benefits upon the nationals, ships, products, etc. of the third state. The beneficiary state is normally not entitled to claim for its residents the benefits which the granting state extends to the nationals of the third state. Although resident creates also a certain relationship between a person and a state, this is not the same relationship as that of the link of nationality. These two relationships are not interchangeable. However, the expression "same relationship" has to be used with caution because, to continue the example, the relationship between State A and its nationals is not necessarily the "same" as the 
relationship between State B and its nationals. Nationality laws of States are so diverse that the sum total of the rights and obligations arising from one States's nationality laws, might be quite different from that arising from another States's nationality laws (United Nations, 1979: 22).

MFN clause may define exactly the conditions for the operation of the clause, namely, the kind of treatment extended by the granting State to a third state that will give rise to the actual claim of the beneficiary state to similar, the same, equal, or identical treatment. If as is the usual case, the clause itself does not provide otherwise, the clause begins operate, i.e.,, a claim can be raised under the clause if the third state (or persons or things in the same relationship with the third state as the persons or things mentioned in the clause with the beneficiary state) has actually been extended the favours that constitute the treatment. It is not necessary for the beginning of the operation of the clause that the treatment actually extended to the third state, with respect to itself or the persons things concerned, be based on a formal treaty or agreement. The mere fact of favourable treatment is enough to set in motion the operation of the clause. However, the fact of favourable treatment may consist also in the conclusion or existence of the agreement between the granting state and the third state by which the latter is entitled to certain benefits. The beneficiary state, on the strength of the clause, may also demand the same benefits as were extended by the agreement in question to the third state. The mere fact that the third state has not availed itself of the benefit, which are due to it under the agreement concluded with the granting state can not absolve the granting state from its obligation under the clause (United Nations, 1979: 23).

\section{Varying Application MFN Principle in International Investment Law Regime}

The MFN principles in international investment law aim at ensuring an equality of competitive conditions among foreign investors intending to invest into the beneficiary state (Stephan W Schill, 2009: 500). In this case, it is very plausible for foreign investors ensuring adequate legal certainty by asking to the beneficiary state not to provide discrimination treatment that could put them at the competitive disadvantage. Discrimination in this regard include providing more favourable treatment from granting 
state to other investor from other country. The MFN principle serves as a mechanism to create conditions in which foreign investors from many countries have equal opportunities to compete fairly in host country.

In international investment law, there are three limitations must be considering on the operation of MFN clauses. Firstly, MFN clauses should be understood as granting access solely to more favorable treatment provided after the agreement is negotiated, and not to any preexisting more favorable treatment. Secondly, the "favorability" of a particular type of treatment should be assessed not with respect to the specific investor invoking MFN clauses, but with respect to the entire class of investors covered by the clause. Finally, MFN clauses do not merely provide to the beneficiary any more favorable treatment provided to a third party, but also simultaneously exclude the beneficiary's access to the treatment originally promised. Moreover, these latter two limitations can sometimes combine in a way that results in an investor actually being harmed by an MFN clause rather than benefited by it (Tony Cole, 2012: 568).

The operation of MFN clauses in international investment law presupposes a relationship of at least three states: State $\mathrm{A}$ is a granting state entering into an obligation vis-a-vis, State B as the beneficiary state to extend rights and benefits granted in a specific context to any third State C. The consequence of the MFN clause in the treaty between A and B is that State B can invoke and rely on all benefits State A grants with vis-a-vis State $\mathrm{C}$ as long as the granted benefit is within the scope of application of the MFN clause in the relationship between A and B. The treaty containing the MFN clause between A and B is designated as the "basic treaty" because it contains the basis for incorporating more favorable conditions granted in a third-party treaty into the treaty relationship between A and B (Stephan W Schill, 2009: 507).

Moreover, the third-party treaty (between A and C), however, does not modify the basic treaty (the relationship between A and B). It does not govern the relationship between the parties of the basic treaty as the applicable international treaty. Rather, the content of the third-party treaty becomes operative by means of the basic treaty's MFN clause. MFN clauses therefore do not break with the inter partes effect of international treaties (Stephan W Schill, 2009: 507). 
The third-party treaty is thus incorporated by reference and ipso iure into the relationship between the state parties to the basic treaty without any additional act of transformation (Alejandro Faya Rodriguez, 2008: 99). For this reason, MFN clauses also have been characterized as "drafting by reference" (Georg Schwarzenberger, 1957: 243). They effectuate automatic treaty adaptation without the need for the state parties to the basic treaty to negotiate anew in order to incorporate benefits granted to third countries. The MFN clause thus prevents the granting State from entering into bilateral treaty relations that are more preferential to a third State and put the beneficiary State at a relative disadvantage (Stephan W. Schill, 2009: 508).

The benefits of using MFN clauses are closely connected to the benefits from multilateral ordering (Peter B. Kenen, 2000: 19-62). First, MFN treatment prevents market distortions stemming from the imposition of unequal transaction costs that result from unequal standards of protection offered to investors from different states. Second, MFN treatment protects the value of concessions made between the contracting parties to the basic treaty. It upholds the bargain states struck by preventing either one of them from hollowing out the content of the basic treaty by granting more favorable protection to a third state and thereby making investments from the original treaty partner comparably less attractive. Third, MFN treatment allows for a more transparent framework for international investment relations because it dispenses with the necessity to adhere to complicated, and thus costly, rules on the origin of capital in order to ascertain the applicable standard of protection. Fourth, apart from these primarily economic aspects, MFN treatment also has broader implications for the structure of international relations in implementing equal treatment among nations. It prevents states from forming economic alliances to the detriment and to the exclusion of other States, which, in turn, might increase the potential for tension or even military conflict (Richard Pomfret, 1988: 29-59). In this context, MFN treatment also protects smaller states against the influence of larger and more powerful states, as it precludes hegemonic State behavior in imposing patterns of preferential treatment to the exclusion of other States. MFN treatment thus breaks with bilateralism as an ordering paradigm for international relations by extending rights and benefits from a third-party relationship to the treaty relationship containing the MFN clause. Finally, MFN 
treatment has a constitutional function, because it locks States into a multilateral framework and makes abandoning standards of protection adopted previously more difficult. MFN clauses therefore are an instrument to push towards an order that is multilateral in substance even though it is based on bilateral treaties (Stephan W. Schill, 2009: 509).

There are many variations on the MFN clause in investment treaties, but it is possible to classify them according to three main criteria. First, a distinction may made on whether MFN is a stand-alone clause attached to a national treatment clause or attached to another clause in the Bilateral Investment Treaty (BIT).

For the first case, it can examine at Article 3.2 of the China-Benin BIT (2004) (http://investmentpolicyhub.unctad.org/IIA):

"Neither Contracting Party shall subject investments and activities associated with such investments by the investors of the other Contracting Party to treatment less favorable than that accorded to the investments and associated activities by the investors of any third State."

But sometimes MFN is combined with the national treatment obligation in BITs, such as in article 3.2 of the Netherlands-Burkina Faso BIT (2001): (http://investmentpolicyhub.unctad.org/IIA):

"Each Contracting Party shall grant most particularly to these investments treatment that is not in any way less favourable than that afforded to investments made by its own nationals or by the nationals of any third State, in all cases the treatment that is the most favourable to the national concerned."

Second, a distinction can be made on whether the MFN clause specifies or not the type of "treatment" covered. The majority of traditional BITs do not specify the scope of application of MFN - that is, the categories of measures covered-like the examples cited above. Some BITs, however, are more precise and state, for example, that (http://investmentpolicyhub.unctad.org/IIA):

"Neither Contracting Party shall in its territory subject nationals or companies of the other Contracting Party, as regards their management, maintenance, use, enjoyment or disposal of their investments, to treatment less favourable than that which it accords to its own nationals or companies or to nationals or companies of any third State." 
Conversely, other BITs refer directly to all the provisions contained in other BITs. Indeed, they state that MFN is applicable to all the provisions of the BIT from definitions through to the settlement of disputes. This type of BIT, therefore, expressly authorizes the import of any more favourable provision from other BITs corresponding to those covered by MFN. Note that although several British BITs contain this clarification, not all do, including those made after 2000 (http://investmentpolicyhub.unctad.org/IIA).

Article 4.2 of the Colombia-Switzerland BIT (2006) refers solely to fair and equitable treatment (FET) (http://investmentpolicyhub.unctad.org/IIA):

"Each Party shall ensure fair and equitable treatment within its territory of the investments of investors of the other Party. This treatment shall not be less favourable than that granted by each Party to investments made within its territory by its own investors, or than that granted by each Party to the investments made within its territory by investors of the most favoured nation, if this latter treatment is more favourable."

Finally, one can make a distinction on whether or not the MFN clause incorporates a criterion of comparison between foreign investors. Thus, a growing number of BITs state that a comparison will be made between investors or investments located "in like circumstances or situations":

"Each Contracting Party shall in its territory accord to investors of the other Contracting Party and to their investments treatment no less favourable than the treatment it accords in like circumstances to investors of any third country and to their investments ... with respect to investment and business activities.

Each party shall accord to an investor of the other party and to a covered investment, treatment no less favourable than the treatment it accords in like situations, to investors of a third country and to their investments ... in its territory.

The term "circumstance" is used more frequently than "situation" in investment treaties, and the legal implications of the choice of the one rather than the other are yet to be determined.

Other treaties go further and provide guidelines for tribunals that must rule on whether like circumstances are present. This is the case of article 17.2 of the Investment Agreement for the Common Market for Eastern and Southern Africa (COMESA) Common 
Investment Area (CCIA):

"For greater certainty, references to 'like circumstances' in paragraph 1 of this Article requires an overall examination on a case-by-case basis of all the circumstances of an investment including, inter alia:

(a) Its effects on third persons and the local community;

(b) Its effects on the local, regional or national environment, including the cumulative effects of all investments within a jurisdiction on the environment;

(c) The sector the investor is in;

(d) The aim of the measure concerned;

(e) The regulatory process generally applied in relation to the measure concerned; and

(f) Other factors directly relating to the investment or investor in relation to the measure concerned; and the examination shall not be limited to or be biased towards any one factor"

Most BITs do not refer to "like circumstances" and do not provide a criterion for comparisons between investments. It should be noted that in the WTO, MFN is only applied between "like" foreign products (GATT) or "like service providers" (GATS). The notion of likeness is fundamental and has been the subject of abundant jurisprudence by the Appellate Body, particularly as part of national treatment.

Some typical formulations can also be found. Article 3 of China-Latvia BIT (2006) grant MFN "without prejudice to the laws and regulation” of the host state or under Article 10.2 of Brazil-Malawi Investment Cooperation and Facilitation Agreement (2015) state that "subject to the exceptions established by law and to applicable legal requirements." This type of provision lays down that a state may reserve the right to have discriminatory rules in national law, on condition that the laws in question are themselves applied in a non-discriminatory fashion (Suzy H. Nikiema, 2017: 5). Moreover, although MFN clauses generally protect investors and their investments, some BITs limit the benefit of MFN treatment to "investments" without extending it to "investors" as stated in Article 4 of Australia-Uruguay BIT (2000). Finally, regardless of the way in which the MFN clause is written, investment treaties systematically provide for exceptions. 


\section{E. CLOSING}

MFN clauses in investment agreements are worded in a variety of ways. Nonetheless, it does not matter for applying the MFN in international investment law. The differences are depending on the intention of negotiation between states.

\section{BIBLIOGRAPHY}

Books :

Carlton Snyder, Richard, 1948, The Most-Favoured-Nation Clause, New York: Columbia University Press.

Houde, Marie-France, 2005, Most-Favoured-Nation Treatment in International Investment Law, in OECD, International Investment Law: A Changing Landscape, Paris: OECD Publishing.

Kenen, Peter B, 2000, The International Economy, Fourth Edition. United Kingdom: Cambridge University Press.

Lee, Yong-Shik, 2016, Reclaiming Development in the World Trading System, $2^{\text {nd }}$ Edition, United Kingdom: Cambridge University Press.

Schwartz, Warren F. \& Alan O. Sykes, 1997, The Economics of the Most Favoured Nation Clause” in Jagdeep S. Bhandari \& Alan O. Sykes (Eds), Economic Dimensions in International Law: Comparative and Empirical Perspectives. New York: Cambridge University Press.

Trebilcock et al, 2013, The Regulation of International Trade, $4^{\text {th }}$ Edition. London and New York: Routledge.

\section{Journals}

Cole, Tony, "The Boundaries of Most-Favoured-Nation Treatment in International Investment Law", 33 Mich. J. Int'l. L, , 2012.

Coutain, Bryan, "The Unconditional Most-Favoured Nation Clause and the Maintenance of the Liberal Trade Regime in the Postwar 1870s”, 63 Int'l Org, 2009.

Fietta, Stephen, "Most Favoured Nation Treatment and Dispute Resolution Under Bilateral Investment Treaties: A Turning Point?" 8 Int'l. Arb. L. Rev, 2005. 
Schwarzenberger George, "International Law: As Applied by International Courts and Tribunals. International law as Applied by International Courts and Tribunals", Volume 1. United Kingdom: Stevens, 1957.

Hornbeck, Stanley. 1909. “The Most-Favoured-Nation Clause", 3 Am. J. Int'l. L. 395 ,1909.

Lazer, David, "The Free Trade Epidemic of the 1860s and Other Outbreaks of Economic Discrimination”. World Politics 51.4 (1999) 447-483, 1999.

Nikiema, Suzy H., "The Most-Favoured-Nation Clause in Investment Treaty: IISD Best Practices Series-February 2017”, Canada: International Institute for Sustainable Development, 2017.

Pomfret, Richard, "Unequal Trade: The Economics of Discriminatory International Trade Policies". United Kingdom: B. Blackwell, 1988.

Rodriguez, Alejandro Faya, "The Most-Favored-Nation Clause in International Investment Agreements”, 25 J. Int'l. Arb. 89, 92, 2008.

Schill, Stephan W., "Multilateralizing Investment Treaties through Most-Favoured-Nation Clauses”, 27 Barkeley J. Int'l Law. 496, 2009.

United Nations," Yearbook of the International Law Commission 1978", Vol. 2 Part II. New York: United Nations Publications, 1979.

Ustor, Endre, "First Report on the Most-Favoured-Nation Clause". 2 Y.B. Int'l L. Comm'n 157, paras.10-12, U.N. Doc. A/CN.4/SER. A/1969/Add.I, 1969.

\section{Website:}

http://investmentpolicyhub.unctad.org/IIA access on December 2016 